\title{
ISLAMIZATION AND THE SOCIO-ECONOMIC HISTORY OF JAMBI MALAY
}

\author{
Saidina Usman \\ Email: usman.elqureishi@gmail.com; \\ Constitutional Law Study Program of STAI Ahsanta Jambi, Indonesia.
}

\section{Nori Nopita Sari}

Email: novitaahmadelquraisy@gmail.com;

Early Childhood Islamic Education Study Program of STAI Ahsanta Jambi, Indonesia.

\section{Teguh Adimarta}

Email: teguh.adimarta@gmail.com

English Teacher Education Study Program of STAI Ahsanta Jambi, Indonesia

\begin{abstract}
One theory of the arrival of Islam to the archipelago states that the arrival of Islam was brought by merchants. There are those who say that the merchants came from Gujarat and some who got direct opinions from Arabia. Not a few also disagree that Islam was brought to the archipelago by traders, but rather by religious scholars from Arabia. This paper is not to discuss the pros and cons of this theory, but focuses on the relationship between trade activities and Islamization in the Jambi remoted area. By using historical research methods covering heuristics, internal and external criticism, interpretation and historiography, this article argues that the process of Islamization in Jambi is similar to the processes and flows of Islamization that occurred in other regions in Sumatra.
\end{abstract}

Keywords: Islamization, Trade, Remoted Upstream Jambi.

\section{PRELIMINARY}

The growth of the centers of world civilization led to the emergence of trade networks to meet the needs of various commodities. A trade network called the silk route developed between Asia and Europe since the first centuries AD. In the 10th century the silk route was a very important route for mutual relations, be it trade, culture, religion or knowledge. It not only offered the commodity silk, but also the spice commodity which was very much 
IJIERM: Vol. 2 No. 2 May - July 2020

needed in Europe, because spices became the main commodity of world trade, so that this trade route was better known as the spice route. ${ }^{1}$

Tjandrasasmita stated that international trade, especially the dense spice trade in the trade network in the archipelago, was a connecting factor between spice-producing areas, such as the pepper-producing areas in Sumatra and Java, the nutmeg producing areas in Central Maluku, the clove-producing areas in North Maluku. ${ }^{2}$ Ricklefs added that the relationship between regions due to trade factors also seemed to allow the establishment of a network for the spread of Islam in the archipelago. The spread of Islam covered areas or spiceproducing areas in eastern Indonesia, which originally came from Sumatra. It was also said that the areas with the strongest Islamic influence were the most important areas in international trade, including: the eastern coast of Sumatra in the Malacca Strait, the Malay Peninsula, the north coast of Java, Brunei, Sulu and Maluku. ${ }^{3}$

Based on this background, problems arise that must be answered, including regarding the network and development of trade in Jambi during the Islamic development phase, considering that during that period the trade era began, with many introductions to more advanced means of transportation, namely large ships which across the ocean to reach Malay waters. Trade and Islamization seem to have an interplaying correlation. This is due to Jambi's position as one of the spice-producing centers and its open geographical conditions, allowing contact with foreign traders including Islamic traders from various regions, both from outside and from other parts of the archipelago. The emergence of Islamic kingdoms, is one indication of the development of trade, at the same time it also shows the existence of Islamic influence that comes from outside the Jambi Malay area. Based on this, the problems that can be formulated are as follows: first, how is the development of Jambi Malay Islamization? second, how can the trade and Islamization network develop in line with the Jambi remoted area?

Thus, the aim of the research or writing of this article is to briefly explain the development of Jambi Malay Islamization. In addition, it also tries to explain how the commercial network was formed in the Jambi Malay area.

\footnotetext{
2013. p. 18

2 Tjandrasasmita, Uka. 2009. (ed.), National History of Indonesia III. Update Edition (Jakarta: Balai Pustaka).

${ }^{3}$ Ricklefs, MC 2008. History of Modern Indonesia 1200-2004 (Jakarta: PT Serambi Ilmu Semesta.) p. 23
}

${ }^{1}$ Wuri Handoko, Commerce and Islamization, Journal of Archeology, Vol. 22, May 


\section{METHOD}

In terms of the methodology used in the writing of this article is to use historical research methods that cover heuristics, internal and external criticism, interpretation and historiography. At the data collection stage (Heuristic), the author first determines the topics to be discussed, namely Islamization and the socio-economic history of Malay Jambi. Data collection in the form of library research was carried out at the Jambi Provincial Library, the Jambi City Regional Library and Archives Agency, the Jambi Province Culture and Tourism Office, and at the Jambi state museum.

The next stage after the data is found is the process of internal and external criticism to see the authenticity and reliability of a data or source obtained. Then after the source criticism process is carried out, then the next step is interpretation, carried out based on the facts and also the data obtained. In the interpretation stage, the primary sources that have been obtained are compared to other sources, both secondary and tertiary. At this stage the writer tries to link one fact to another, so that a complete picture of events and a related chronology is obtained. Furthermore, the final stage is historiography; that is, arranging the narrative in this article in a chronological order.

\section{LITERATURE REVIEW}

The relationship between Islamization and trade, is an issue that continues to be discussed. Trade on the one hand and Islamization on the other seem like two coins crisscrossing each other. Although there are differences of opinion among experts on that matter. Again to quote what Ricklefs said that between Islam and trade there seems to be some kind of connection, even though there are many unanswered questions, considering that trade by Muslims existed several centuries before the Islamization of the Archipelago which only occurred in the 13th century and especially 14 th and 15 th centuries $\mathrm{AD}^{4}$ This explanation illustrates that the trade process in the archipelago took place long before Islam developed, so that if Islamization had taken place since the beginning of the trade era by the nations spreading Islam, Islam should have grown and developed since that time. However, one thing cannot be denied, that the ongoing trade process has strengthened the existence of Islam in the archipelago.

In line with the theory expressed by Ricklefs, Tjandrasamita also agrees that the emergence of trade routes since the early days has triggered the

\footnotetext{
${ }^{4}$ See Ricklefs, History of Modern Indonesia. Thing. p. 37-38
} 
IJIERM: Vol. 2 No. 2 May - July 2020

establishment of trade networks and the growth and development of the central cities of the empire, with their port cities from the 13th-18th century $\mathrm{AD}^{5}$ It seems that there are episodes where important changes have occurred when the influence of Islam and the growing and developing trade has had a major impact on various changes, be it social, political or cultural. The meaning that the increasing relationship between the emergence of the influence of trade and Islam as the main aspect of the economy has brought about major impacts, say the period of the 16th and 17th centuries, important changes occurred in the social, political, and cultural fields which had a lot of influence on the general economic situation, which was This is the impact of the increasingly widespread influence of Islam which gave birth to agrarian kingdoms embracing Islam. The spread of Islam is a clear reflection of the existence of this wide network of relationships and the spread of religion itself has helped to accelerate the process of expanding the trade network. ${ }^{66}$

The Middle Ages established close trade relations between South Arabia, particularly Maskat, the Persian Gulf and the archipelago. It can be said that it was the Arab navigators and traders who introduced Islam to the archipelago. A number of Arabs had settled in important ports of the archipelago and some even had a strong influence on the political future of the indigenous groups and the establishment of Arab colonies. ${ }^{7}$ From Berg's explanation, it can be concluded that the introduction or initial interaction of Islam in the archipelago, including in Jambi, was carried out through trade, this is because Arab (Islamic) traders introduced Islam as well as in an effort to carry out trading activities.

\section{DISCUSSION}

\section{Jambi Before Islam}

In the view of some prominent historians, Jambi was the location of the Malay kingdom until around the seventh century AD. Wolters even confirmed that this kingdom was a large kingdom in Southeast Asia that had led a mission to China in 644 AD. ${ }^{8}$ Regarding the location of the Malay

5 Tjandrasasmita, Uka. 2009. Islamic Archeology of the Archipelago. (Jakarta: Gramedia Popular Libraries.), p. 39

${ }_{6}$ Belwood, Peter, 2000. Prehistory of the Indo-Malaysian Archipelago. Revised Edition. (Jakarta: Gramedia Pustaka Utama)

7 Berg, LWC van den. 2010. Arabs in the archipelago. Cet. 1. Jakarta: Bamboo Community.), p. 95

8 OW Wolters, Early Indonesian Commerce: A Study of the Origins of Srivijaya (New York: Cornell University Press, 1967), p. 237. Hereinafter abbreviated as Early Indonesian Commerce. 
kingdom - which later the Malay name used to this day is taken from the name of this kingdom - al-Attas also wrote in his masterpiece in the field of history of Historical Fact and Fiction that the Malay kingdom was in Jambi and Sriwijaya in Palembang. ${ }^{9}$

In $671 \mathrm{AD}$ a priest from China named I Ching ${ }^{10}$ on his voyage from Guangzhou to India he noted that he had stopped in this area of the Malay kingdom, as well as on his way back to China who had also stopped in Malay in 685 AD. ${ }^{11}$ During his journey, he made notes on where the Malay term came from the word Mo Lo Yeu. And then after that the term Malay was also widely mentioned in Chinese news, and was even written on a Tanjore inscription from South India in 1030 AD with the spelling "Malayuir". ${ }^{12}$

When viewed based on old Chinese records, indeed the name Malay was discussed first, namely in the year 644-645M where in these years the Malay kingdom sent envoys to China, while the name Shih-li-fo-shih (Sriwijaya) was only mentioned by I Ching in 671M. ${ }^{13}$ If that is the fact, then it is possible that the Srivijaya kingdom was once under the control of the Malay kingdom, and then tried to free itself and rise again to become a new power. ${ }^{14}$

Although finally Sriwijaya could really fulfill his dream of becoming a new power and making Malay his vassal country, in $853 \mathrm{M}$ and $871 \mathrm{M}$ the

9 Syed Muhammad Naquib al-Attas, Historical Fact and Fiction (Kuala Lumpur: Universiti Teknologi Malaysia Press, 2011), hereinafter referred to as Historical. Regarding the use of a Malay name taken from the name of the Jambi Malay kingdom, it is difficult to argue that the Malay country is located in Jambi. The determination of this place is based on legacy evidences in the form of inscriptions which strengthen the conclusion that the Malay kingdom was located in Jambi today. Then also the results of the study of coastline measurements show that in the seventh century Jambi was located in an area that was very compatible in controlling the traffic of the Malacca Strait. This corresponding royal position was the reason Srivijaya tried to conquer Malays for the sake of economic interests. This is consistent with the statement of the I Ching in 685 who stopped for the second time on his way from India that "Malay has now become part of the Srivijaya empire." See Nia Kurnia Sholihat Irfan, Sriwijaya Kingdom (Jakarta: Girimukti Pasaka, 1983), p. 94-95.

${ }^{10}$ Some historians spell his name with I-Tsing.

11 During this voyage I-Tsing stopped in Sriwijaya for six months to study the Sabdawijaya and translate Buddhist texts from Sangkret into Chinese. Then he only stopped in Malay for two months. See J. Takakusu, A Record of the Buddhist Religion as Practiced in India and the Malay Archipelago, 671-695 AD I-Tsing (Oxford: tp, 1896), p. 237.

${ }^{12}$ Read again al-Attas, Historical. Also read the work of an archaeologist Bambang Budi Utomo, Classical Culture of Indonesia in Batanghari (Jambi: Position of Culture and Tourism in Jambi Province, 2011), p. 17-18.

${ }^{13}$ See Nia kurnia Solihat Irfan, Kingdom of Sriwijaya, (Jakarta: Girimukti Pasaka, 1983), p. 94. Hereinafter referred to as Sriwijaya

${ }^{14}$ Wolters, Early Indonesian Commerce, p. 241. 
IJIERM: Vol. 2 No. 2 May - July 2020

Malay countries were still able to send envoys to China. The attitude of this Malay country was considered inappropriate by Sriwijaya because only an independent country could send envoys, while the Malay country was still under Sriwijaya's control. ${ }^{15}$ Wolters assessed that the success of the Malay country in sending envoys to China even though it was under Sriwijaya's rule was a form of Sriwijaya's negligence and weakness in providing supervision to the Malay country. ${ }^{16}$

According to Wolters also, the other side of the cause of the weakening of Srivijaya's influence on the conquered countries was the attack from Colamandala. Negeri Melayu took advantage of this situation to get back up. Finally, Prince Suryanarayana in Malayupura (Malay) succeeded in holding the reins of power in Suwarnapura (Sumatra) as stated in the inscription in Sri Lanka during the reign of Vijayabahu in 1055-1100. ${ }^{17}$ This also shows that by the middle of the 11th century, the Malay country had succeeded in freeing itself from the influence of Srivijaya power, both politically and economically. This success is evidenced by the mention of the name Jambi country (Chan pi) in Chinese chronicles dated $1079 \mathrm{AD}, 1082 \mathrm{AD}$, and $1088 \mathrm{AD}$, this chronicle states that the Malays in Jambi sent envoys to China, and by accepting the envoy as a form of recognition from the Chinese kingdom to the status of the Malay country as an independent country. ${ }^{18}$ Before the appearance of this Chinese chronicle, Nilakanta Sastri in his research mentioned that in the Solok Sipin area ${ }^{19}$ also found a statue of a makara dated 1064 AD and the name of a Malay official named Dharmavira was found. ${ }^{20}$ it means that in the eleventh century the Malay kingdom rose again and started its royal activities.

The Jambi Malay Kingdom grew rapidly in 1183 AD. This can be seen from the expansion of the area carried out to reach the Grahi area, the

15 WP Groeneveldt, Historical Notes on Indonesia and Malaya, Compiled from Chinese Sources (Jakarta: Bhratara, 1960), p. 63.

16 OW Wolters, The Fall of Srivijaya in Malay History (Oxford: Oxford University press, 1970), 41-42. Hereinafter referred to as The Fall of Srivijaya.

${ }^{17}$ Wolters, The Fall of Srivijaya, p. 92-93.

${ }^{18}$ F. Hirth and WW Rokhill, Chau ju kua: His Work on the Chinese and Arab Trade in the Twelfth and Thirteenth Centuries (Saint Petersburg: Imperial Academy of Science, 1911), p. 66.

${ }^{19}$ The Solok Sipin area is currently part of the Jambi port area, and there are several archaeological sites here.

${ }^{20}$ See KA Nilakanta Sastri, History of Srivijaya (Madras: Madras University, 1949), 83. See also Goerge Coedes, The Indianized States of Southeast Asia(Kuala Lumpur: Universiti Malaya Press, 1968), p. 147-148. Hereinafter only abbreviated, The Indianized States. 
northern part of the Melaka peninsula. An inscription dated 3 Jesta 1105 Saka found in Grahi is evidence of the influence of the Malay kingdom here. This Grahi Parasasti mentions that Mahasenopati Telanai was ordered to make this inscription on the orders of Maharaja Srimat Trailokyaraja Maulibhusana warmadewa (1208-1286) who was then king of Malay. ${ }^{21}$ If the fact is that the Malay kingdom has the influence of its power to the Grahi area, then it is certainly not impossible that the nearby areas such as the countries that existed in Sumatra in the 12th century are still in existence or areas of the former Srivijaya kingdom that have been separated from the influence of the kingdom. Sriwijaya, has also become part of the Malay kingdom at that time.

The above view is also reinforced by sources from Java, where the Pararaton and Negarakertagama books do not mention the role of Srivijaya in the 13th century AD. The Pararaton Book, for example, actually notes that in 1275 the Pamalayu incident which meant an expedition to the Malay country occurred. This expedition was carried out at the initiative and order of the king of Singosari, namely the king of Kartanegara, to send his troops to Malay on a mission of friendship. ${ }^{22}$ With the facts mentioned by the Pararaton book, it can be clearly understood that in the 13th century Malay was a large kingdom that controlled Sumatra and had conquered Sriwijaya. If the Srivijaya kingdom was still in existence at that time, Kartanegara would certainly have ordered the army and its entire expeditionary team to the Sriwijaya kingdom in Palembang to cooperate.

In the book Nagarakertagama by Empu Prapanca in 1365 AD, it is also stated that the whole area of Sumatra as Bhumi Malayu. ${ }^{23}$ Thus, the fact that also calls the Malay kingdom the kingdom of Suwarnabhumi is appropriate, because in the 13th century $\mathrm{AD}$ was the peak period of the heyday of the Malay kingdom which controlled the countries that existed in

${ }^{21}$ Look again at George Coedes, The Indianized States, 179. To prove that king Srimat Tribhunaraja Mauliwarnadewa was the king of Malay at that time by looking at the statue of Amoghapasa dating to 1208 Saka (1286) found in Jambi which mentions that the King of Melayu at that time was Srimat Tribhurnara Mauliwarnadewa. Look again at Nia Kurnia Sholihat Irfan, Sriwijaya (Jakarta: Girimukti Pasaka, 1983).

22 See R. Pitano Hardjowardojo, Peraraton (Jakarta: Bhratara, 1965), 37. And 46. Regarding the purpose of establishing this friendly relationship, besides showing the existence of the Malay kingdom, it was also to guard against attacks from the Mongol kingdom to the archipelago at that time. Read also the free writing of a historian from Jambi Junaidi T. Noor, Senjakala: glancing at Jambi's historical trinkets (Jambi: Heritag Publisher, 2008).

23 Slamet Muljana, Nagarakretagama and Its Historical Interpretation (Jakarta: Bhratara, 1979), 279-280. See also Muhammad Yamin, Gajah Mada (Jakarta: Balai Pustaka, 1974), p. 58-59. 
IJIERM: Vol. 2 No. 2 May - July 2020

Sumatra and even to the northern part of the Melaka Peninsula at that time.

Before Hindu-Buddhist influence entered the Jambi area, the people who inhabited the Jambi area had a basic belief, namely animism and dynamism. Animism and dynamism are not only in Jambi, but are also basic beliefs everywhere in the archipelago. ${ }^{24}$

As emphasized by al-Attas that before the arrival of Islam, the MalayIndonesian archipelago had already been visited by other religions such as Hinduism and Buddhism and then added by local beliefs such as animism, dynamism and so on. ${ }^{25}$ Husin Thalib also mentioned the same thing, that before the arrival of Islam to Southeast Asia, the Malay people were animists and Hindus, which explains the extent of the practice of Hindu-based ancient beliefs in Malay culture and language. ${ }^{26}$

The practice of this belief in the culture of the Jambi people can be seen when they want to build a house or will carry out gardening and farming activities, by first calling the spirits of the ancestors. ${ }^{27}$ to then be adored and asked for blessings. Likewise, when disaster or illness occurs, through the services of certain people this ancestral worship ritual will be carried out. ${ }^{28}$

During historical times, evidence of the existence of Hindu-Buddhism in Jambi was also found before Islam, as can be seen from the inter-island relations marked by the spread of ancient Malay. Several archaeological site discoveries were found using ancient Malay, found in South Sumatra (Palembang), Jambi (Karang Berahi), Kota Kapur (Bangka-Belitung), Nakhon Srithamarat, Thailand (Vat Phra Borom), Luzon, Filifina (Laguna), Java West (Kebon Kopi), and Central Java (Gondosuli and Bukateja). ${ }^{29}$

${ }^{24}$ Zainuddin. Et al, Jambi Regional Education History (Jakarta: Depdikbud, 1982), p. 1.

${ }^{25}$ Al-Attas: IDSKM, p. 12.

26 "Prior to the coming of Islam to south-east Asia, the Malay were followers of animism and Hinduism, which explains the extent of Hindu based antiquated practices in Malays culture and language" See: Husin Thalib, Islam and Ethnicity in Malay Politics (Oxford: Oxford University Press, 1990), p. 13.

${ }^{27}$ Ancestor is a term for referring to the spirits of ancestors or spirits of people who have long died and are considered to have advantages.

${ }^{28}$ Rituals like this in some places are still rooted in the village community in that it is their belief in the existence of the spirits of their ancestors (ancestors), where the ghosts or those who live in their neighborhood, in the jungle dark, unoccupied old houses, under rendang wood staples. According to some residents, the ghosts or spirits of the ancestors have various forms, some are short, dwarf, and are pretty, and some are creepy to those who see them. see Kadir Sabur, Progressive Theology; Revealing Asy'ari Theology in the Doctrine of Malay Society (Jambi: Sulthan Thaha Press, 2008), p. 275.

29 Bambang Budi Utomo and Nik Hasan Shuhaimi, Incription in ancient Malay in Southeast Asia (Bangi: Institute of Nature and Tamaddun Melayu (ATMA), 2009). 


\section{Jambi After the Arrival of Islam}

In the Sumatra region, the Jambi plains in the southern part are bordered by Palembang, in the north it meets Indragiri in Riau, and in the west is bordered by Minangkabau, which of course has a major impact on the social and religious development of the Jambi people. ${ }^{30}$ However, until the end of $1800 \mathrm{AD}$, there was no clear record of historical edicts and the development of Islam in Jambi. It was only after entering the 19th century that Jambi began to have a number of local sources written by Jambi clerics and people from the Jambi sultanate. These local sources are important sources for observing the development of Islamic history in Jambi in the 19th20 century AD. One of the princes of the Jambi sultanate, named $\mathrm{Ng}$ Lebih Sutho Dilogo ${ }^{31}$, for example, he is said to be the author of a text on the history and origin of the Jambi sultanate. In his manuscript, he also mentioned the early history of Islam in Jambi. ${ }^{32}$

However, the use of local sources, written or oral, is not without weakness. Not a few announcements in Jambi regional manuscripts contain myths and legends, including mention of places and years that are difficult to trace. Therefore, it needs in-depth analysis to prove historical facts and legends. Apart from these weaknesses, Vansina emphasizes the importance of local historiography as an important historical source. Local historiography is a medium that has long been used to record the history of a society and has become an official tradition that has been passed down from generation to generation. ${ }^{33}$ Local historiography is the closest information about the life of a society.

In the text of the Jambi Charter Enumeration Law (hereinafter referred to as UPPJ) it is stated that at first the island where Ahmad Barus II was stranded was full of idols, which he later destroyed. Because of his activities on the island, Ahmad Barus II is better known as Datuk Paduka Berhala. ${ }^{34}$ On the site of his grave on Berhala Island, it is written that Ahmad

${ }^{30}$ Elsbeth locher-Scholter, Sumatran Sultanate and Colonial State: Jambi and the Rise of Dutch Imperialism, 1830- 1907, trans. Baverley Jackson (Ithaca. NY: Cornell University, Southeast Asia Program, 2004), p. 25.

${ }^{31}$ His name is mentioned in the SRJ text as the author of the SRJ. But there is nothing about him other than mentioning his service as the royal clerk at that time.

32 Ali Muzakkir, Islamic Thought in Jambi: Strengthening Islamic Studies through Local Manuscripts (Jambi: Sulthan Thaha Press, 2011), p. 15-36.

33 Jan Vansina, Oral Tradition: A Study in Historical Methodology (Chicago: Aldine, 1965), p. 154-157.

34 UPPJ, 7. 
IJIERM: Vol. 2 No. 2 May - July 2020

Barus II allegedly came to Jambi in 864/1460 and died in 886/1480 AD. ${ }^{35}$ Because of the location of his grave on the island, Ahmad Barus II is better known by the people of Jambi as Datuk Paduka Berhala. ${ }^{36}$ The SRJ manuscript also mentions the arrival of Datuk Paduka Berhala.

"Bahawa is the beginning of Islam in the land of Jambi, when Datuk Paduka Berhala became king with his wife named Tuan Putri Selara Pinang Masak who was in Tanjung Jabung". ${ }^{37}$

If that year can be used as the basis, it can be said that Islam entered Jambi since the middle of the 15th century. Ahmad Barus II or Datuk Paduka Berhala, who is said to be an important figure in the spread of Islam to Jambi, is even described as having a genealogy to the family of the Prophet Muhammad:

"Originally Datuk Paduka Berhala, the king of Turkey, descended from Sulțan Sayyidinā Zaynal bin Sayyidinā Husayn bint Fatimah Zahara bint Sayyidina Rasul, became king with his wife Tuan Putri Selara Pinang Masak king of Pagaruyung in Jambi land, residing in Tanjung Jabung. "38

The story of the Islamization of the rulers and local residents in the archipelago, which was preceded by the arrival of a Muslim from Arabia, Persia, Turkey, or a dream of meeting the Prophet, is a form of the flow of stories of the Islamization of local rulers and people in the archipelago. ${ }^{39}$ For example, the popularity of Turkey is also found in Tambo Minangkabau. ${ }^{40}$ Likewise with the story of the Gayo community in Aceh. ${ }^{41}$ From the 16th century until the 19th century, the Turkish Uthmāni dynasty was seen as having the power and being able to provide assistance to protect the Islamic world from the interference of European nations. Several sultanates in the archipelago immediately established political relations with Turki Uthmāni,

${ }^{35}$ In the manuscript, there is no mention of the exact year. The mention of the year above is based on data from the study results of J. Tideman and PL F Sigar, Djambi, (Amsterdam: Colonial Institute, 1938).

36 UPPJ, 7.

${ }^{37}$ SRJ, 19.

${ }^{38}$ SRJ, 19.

${ }^{39}$ R. Jones, Ten Conversion Myths From Indonesia, in Nehamia Levtzion (ed.), Conversion to Islam (New York: Holmes \& Meier Publishers, 1979), 129.

${ }^{40}$ Datuk Sangguno Dirajo, Mustika Adat Alam Minangkabau (Djakarta: Ministry of P $\& \mathrm{~K}, 1955)$.

${ }^{41}$ Martin van Bruinessen, "Muslim of the East Indies and Tea Chalipate Question" in Studia Islamika, 2,3 (1995), p. 120-140. 
and had given hopes of military assistance to expel the Dutch from their homeland. ${ }^{42}$ It is in this context that it can be understood if the local Jambi texts also link the spread of Islam and the lineage of the Jambi kings with the Turks. In fact, one of the Jambi sultans, Sulțan Ṭāha Shaif al-Dīn, had several times asked Turkish Uthmāni for help in his efforts to oppose the Dutch in Jambi. ${ }^{43}$ The inclusion of the story of the Turks in the history of Islam in Jambi is a form of influence from Sulțan Țāha Shaif al-Dīn on the writing of historical texts in Jambi.

Apart from the story of a Muslim from Turkey who is considered to have played an important role in the spread of Islam, the oral history of the people of Jambi also tells of the arrival of a Muslim from Arabia, to be precise from the Hadramaut area named Sayyid Husain bin Ahmad Baraqbah (d. $1156 / 1743$ ). There are no written records of his life. But the oral history of the people of Jambi states that Husain Baraqbah was one of the people who played an important role in spreading Islam to Jambi. He sat in the village of Chinatown, which was the residence of a number of Chinese traders, and he met a very rich man named Sin Tay. ${ }^{44}$ Husayn Baraqbah married Sin Tay's son, named Sing Ing. Because of this marriage, many Chinese citizens in Jambi embraced Islam, including Sin Tay. 45

In the 17 th to 18 th centuries, there were also two people from Minangkabau who spread Islam to Jambi named Bagindo Bujang and Keramat Qur'an. Another interesting story in the story of Islamic teaching in Jambi is about a person named Ketib (khatib) Jambi. This Jambi leader is said to have studied Islam as far as Mecca. Due to the breadth of his knowledge he once issued words that resembled the concept of Wahdat al-Wujūd: 'smaller than sagi: earth and sky are contained by Nyo [a ${ }^{46} \mathrm{It}$ is indeed difficult to trace further these edicts, whether they are historical facts or just legends.

Almost all community groups and local rulers in Sumatra easily

\footnotetext{
42 Martin van Bruinessen, "Muslim of the East Indies and Tea Chalipate Question" in Studia Islamika, 2, 3 (1995), 120-140.

43 Anthony Reid, "Pan-Islamism in the Nineteenth Century in Indonesia and Malaysia", in Nico JG Kaptein (ed.), Chaos and Riots: Three writings on Pan-Islamism in the Indies-East Holland in the Late Nineteenth and Early Twentieth Century (Jakarta: INIS, 2003), $10-13$.

${ }^{44}$ Ibrahim Hadi, "The Influence of Islamic Education on the Jambi Chinatown Society", Thesis at IAIN Sunan Ampel, Surabaya, (1973), 70.

${ }_{45}$ M. Khatib Quzwain, "Islam in Jambi in the 17th Century: A Study on the Entry and Development of Islam in Jambi", Seminar Paper on "The History of Islam in Jambi", (1981), 6-7.

${ }^{46}$ M. Khatib Quzwain, "Islam in Jambi", 8.
} 
IJIERM: Vol. 2 No. 2 May - July 2020

accepted Islamic broadcasters who came from India and Arabia, among them teaching about the authority and sovereignty of sultan as representatives of God on earth. ${ }^{47} \mathrm{By}$ turning to Islam, the local rulers in the Malay area found it easier to unite with other Muslim communities, not only for trade but also for social, political, and spread of Islam. This unification, said Reid, has created a booming trade that has created prosperity and mass embracing of Islam in the Malay region since the 15th century.

In line with this view, Elsbeth Losher-Scholten is of the view that the development of Islam in Jambi was helped by the establishment of the Jambi Sultanate at the end of the 15th century. ${ }^{48}$ This is in line with the announcement contained in the UPPJ manuscript, although in fact until the end of the 16th century the position of the Jambi Sultanate was still unclear. The existence of the Jambi Sultanate came to power during the time of Sultan 'Abd al-Qahhar (1615-1643). The name Sulțan 'Abd al-Qahār began to be recorded in the history of European nations during trade relations with Britain and the Netherlands. ${ }^{49}$

The Jambi region of the ulu (West) part of the region is heavily influenced by people from the Minangkabau, who came since the mid-17th century. Nearly a century later, the number of Minangkabau people was so large that the highlands of West Jambi were the same socially and culturally as "terminangkabaukan". ${ }^{50}$ One of the oral histories that developed in the people of Rengas Island, Bangko, for example, tells of a person named Hasan Nadil from Minangkabau who came to Jambi to spread Islam. A manuscript of the Koran, written in the 19th century is still preserved on Rengas Island and is believed to be a legacy of Hasan Nadil. ${ }^{51}$ In addition, another manuscript was also found in a more remote area, namely the Muara Madras sub-district.

47 A. C Milner, "Islam and the Muslim State", in MB Hooker, Islam in South-East Asia (Leiden: E. J Brill, 1983), 23-49.

${ }^{48}$ Locher-Scholten, Sumatran Sultanate, 32.

${ }^{49}$ Tjandrasasnita, "The process of Islamization, p. 13-17

${ }^{50}$ Barbara Watson Andaya, "Cash Cropping and Upstream-Downstream Tension: The Case of Jambi in the Seventeenth and Eighteenth Centurie", in Anthony Reid (ed.), Southeast Asia in the Early Modern Era: Trade, Power, and Beliefs (New York : Cornel University Press, 1993), p. 115. Jambi, 18.

51 Interview with Nursali Ghani by Ali Muzakkir, in Ali Muzakkir, Islamic Thought in 


\section{Jambi Malay Economic Development and the Spread of Islam into Remoted}

Geographically, until around the 19th century, Jambi was one of the smallest Malay sultanates in Sumatra. Its territory stretches 350 kilometers from east to west, 220 kilometers from north to south. The Jambi region is directly adjacent to the Palembang residency in the south, the Indragiri sultanate and a number of independent Minangkabau kingdoms, such as Siguntur and Lima Kota to the north, and to the west by the Bukit Barisan mountains, Jambi also borders the Miangkabau plateau. ${ }^{52} \mathrm{Jambi}$ develops in the basin of a river which has many tributaries. Batanghari is the longest meandering river in Sumatra for 800 kilometers, forming the backbone of the region. The main tributaries such as the Tembesi river, Merangin trunk, Tabir river, Tebo river, and Jujuhan river. The existence of these rivers became the main transportation access for the people of Jambi from the early to the 19th century.

As a Malay area which is actually in the central part of the island of Sumatra, Jambi has many interactions with other areas around it, such as Palembang in the south. Jambi and Palembang relations in the 17th and 18th centuries were also very friendly. The two sultanates had several blood relations through marriage and brotherhood ties. "Palembang and Jambi have always until the present time, been friends and live as brothers," said Barbara Watson Andaya. ${ }^{53}$

Although there have been tensions between the two of them several times, basically economic, social, cultural and religious relations are still wellestablished. Colombin said that the collaboration between political and religious forces in Sumatra during the 17th to 19th centuries had created a symbolism of urban society that was open in Minangkabau, Bengkulu, Palembang, Jambi and Riau. ${ }^{54}$ Therefore, it is not surprising that entering the 17 th century the capital of the Jambi sultanate soon grew into a bustling trading port, almost on par with Aceh and Palembang. ${ }^{55}$ It is also in the context of this century that some fragmentary edicts mention that in the 1640 s the Dutch witnessed an increase in the attention of the nobility and residents

52 Locher-Scholten, Elsbeth, 2008, Sultanate of Sumatra and the Colonial State, Jambi-Batavia Relations (1830-1907) and the Rise of Dutch Imperialism (Jakarta: Bamboo Community), p. 39.

53 Barbara watson Andaya, To Live as Brothers: Southeast Sumatra in the Seventeenth and Eighteenth centuries (Honolulu: University of Hawaii Press, 1993), p. 2.

${ }^{54}$ Freek Colombijn, "Islamic Influences on Urban Form in Sumatra in Seventeenth to the Nineteenth century" Indonesia and the Malay World, 32 (2004), p. 249-270.

55 Watson Andaya, "Cash Cropping", p. 99. 
IJIERM: Vol. 2 No. 2 May - July 2020

of Jambi in adhering to Islamic teachings. ${ }^{56}$ Then in 1687, a scholar from India, is said to have come to spread Islam to the people of Jambi. ${ }^{57}$

It seems that Islam and the Jambi sultanate had strengthened the growth of Jambi society, until by 1800 , the Jambi area was still almost completely inhabited by the Malays, except for a small number of Chinese and Arabs who were concentrated in the capital of the Jambi sultanate. According to Dutch arsif records, in 1852 the population of Jambi was estimated 60,000 inhabitants. However, the economic wealth of the Jambi region, in the form of nature and mining materials during the Sultanate era, was the cause of the arrival of the Dutch to take the wealth of Jambi. Therefore, entering the 19th century, the Jambi sultanate faced great pressure from the Dutch colonialists. Dutch attention to Jambi was part of its expansion to the southern region of Sumatra, after Palembang was previously controlled. The Dutch succeeded in defeating the resistance of Sultan Fakhr al-Din (1833-1841) in a war on the Rawas river in 1833 and forced Sultan to sign an agreement which essentially gave up part of its territory to the Dutch. ${ }^{58}$

The arrogance of the Dutch certainly faced challenges from the Jambi people. Although not explicitly stated in the Dutch arsif, Islamic motivation was deeply felt in the Jambi war. The Jambi people's resistance led by Sultan TTāha Shaif al-Dīn from 1858 to 1904 was often associated with a group of fanatical Muslims dressed in white. After Friday prayers, several mosques were often used to discuss strategies against the Dutch, which were led by several pilgrims. ${ }^{59}$ The existence of the pilgrims and a group of Muslims they led in expelling the Dutch colonialists in Jambi shows that Islam has had a strong influence on Jambi society since the 19th century.

In terms of economic development, the arrival of Islam to Jambi brought blessings to the economy, especially the lower class people in the upstream part of Jambi. One of the important commodities produced by the people of upstream Jambi is spices in the form of pepper. According to Barbara Watson Andaya, upstream communities are those located in remote areas following the direction of the tributary, where most pepper is supplied from this area. Barbara also added that from an economic perspective as well,

${ }^{56}$ Barbara Watson Andaya and Yoneo Ishii, "Religious Developments in Southeast Asia 1500-1800", in Nicholas Tarling (ed.), Cambridge History of Southeast Asia (Cambridge: CUP, 1992), p. 541.

${ }^{57}$ Reid, From Expansion to Crisis, p. 433.

${ }^{58}$ Locher-scholten, Sumatran Sultanate, p. 76.

${ }^{59}$ Ibid, p. 110-121. 
the upstream refers to the physical environment of economic development characterized by the number of trading points that develop at the intersection of important rivers in Jambi. These trading centers were connected by land routes to Minangkabau and the West coast. While the downstream area was the center of the sultanate which was also a major trade center, where ExportImport activities are carried out. Precisely on the banks of the Batanghari river. Due to the importance and busyness of trading activities in the Btanghari River area, at the end of the sixteenth century, the upstream area of the Batanghari river was declared a migratory area for the Minangkabau people. In the past decades, the arrival and interaction of the Minangkabau people has intensified. They came to trade until they had mixed marriages with the natives of Jambi. So it is not surprising that in certain areas in Jambi, the dominance of Minangkabau customs and culture was very visible until the XIX century. the upstream area of the Batanghari river is declared as a migratory area for the Minangkabau people. In the past decades, the arrival and interaction of the Minangkabau people has intensified. They came to trade until they had mixed marriages with the natives of Jambi. So it is not surprising that in certain areas in Jambi, the dominance of Minangkabau customs and culture was very visible until the XIX century. the upstream area of the Batanghari river is declared as a migratory area for the Minangkabau people. In the past decades, the arrival and interaction of the Minangkabau people has intensified. They came to trade until they had mixed marriages with the natives of Jambi. So it is not surprising that in certain areas in Jambi, the dominance of Minangkabau customs and culture was very visible until the XIX century. ${ }^{60}$

At the beginning of the XVI century, pepper farmers in the upstream Jambi sold their pepper downstream. From there, pepper wholesalers transported pepper to the larger ports in Jambi, namely Palembang, Banten, Gresik and also Fattani on the Malay peninsula. For approximately 60 years, Jambi pepper was not sold downstream, but sold to ports which were popular with the Chinese. The impact is that trade activity in Jambi is still less crowded than its neighbor, Palembang. ${ }^{61}$

The pepper trade in Jambi (which was the main source of income for the people of Jambi at the beginning of the arrival of Islam) continued to grow along with other export-import commodities. In 1710, Jambi's exports

${ }^{60}$ Barbara Watson Andaya, 2016, Life for Brothers in Southeast Sumatra in the XVII and XVIII centuries. (Yogyakarta: Ombak Publisher), p. 37.

${ }^{61}$ Ibid, p. 82 
IJIERM: Vol. 2 No. 2 May - July 2020

were still entirely in the form of pepper. It was only in 1730 that half of Jambi's exports were already in gold. In 1750, again, pepper became the most exported, reaching more than 80 percent. ${ }^{62}$ Increased trade in Jambi at that time made pepper also functioned as a medium of exchange around the XVI to XVII centuries.

The use of pepper as a medium of exchange has made the dynamics and commercial activities in Jambi more excited and interesting. There are two forms of exchange, namely the barter system and the cash system. And one of the groups involved in the pepper system as a medium of exchange was traders from the Portuguese side. They actively traded in Jambi port at the end of the XVI century and the beginning of the XVII century bringing cloth to Jambi, not only for sale, but also to be exchanged for pepper.

Portuguese traders took advantage of the pepper harvest in Jambi, including at the end of the XVI-XVII centuries which reached 40,000 to 50,000 sacks per year weighing 50 pounds per sack. They pursue this moment to the upstream area using small boats to buy pepper. ${ }^{63}$

The triumph of the pepper trade in Jambi was short lived. The end of the 17th century, the people's laziness to plant pepper began to appear. This raises concerns about the palace elite regarding the unstable supply of pepper from farmers, especially from upstream Jambi. According to Andaya, one of the factors causing the people's lack of enthusiasm to plant pepper was the drop in the price of pepper in the European market. This clearly affects the selling price of pepper at the farm level. In addition, the monopoly factor in trading practices by downstream traders also has an effect on the stability of pepper prices for upstream farmers. Farmers in the upstream Jambi shift their crops to cotton and rice. Besides that, their activities are looking for gold (panning) in rivers.

In 1680, Jambi lost its position as the main port of pepper on the east coast of Sumatra after clashes with Johor. This was exacerbated by internal upheaval. In the trade sector there is tension between upstream and downstream, whose functions are between producers and intermediaries. The British left their trading post in Jambi in 1679.

The Jambi sultanate felt the impact of the decline in the pepper trade in Jambi. So far, the sultans and aristocrats of Jambi have been involved in

\footnotetext{
${ }^{62}$ Lindayanti, et al, 2013, Jambi in History 1500-1942, Jambi: Research Center for Historical and Cultural Development of Jambi), p. 76

${ }^{63}$ Ibid, p. 72. see also: Meilink Roelofsz, 2016, Asian Trade and European Influence in the Archipelago Between 1500 and Around 1630. (Yogyakarta: Publisher Ombak), p. 226.
} 
the pepper business. In capital, they borrowed a lot of capital from the Netherlands. When the pepper supply stopped, it got them into big trouble. At the end of the XVIII century the Jambi Sultanate became a vassal state under King Minangkabau in Pagaruyung. ${ }^{64}$

From the point of view of the spread of Islam to the upstream area, it does not appear to have had an effect on the ups and downs of the Jambi people's economy. As previously explained, the upstream areas in Jambi can get to know Islam more deeply through Islamic preachers or preachers who pass through the trade route through tributaries in Jambi to the upstream area. No authentic source has yet been found, whether the preacher also participated in trading when preaching Islam to the upstream area or was it just a ride on transportation. There is still a need for more in-depth research. However, what is clear is that economic development from time to time has become an opportunity for the development of Islamic da'wah for the remoted community of rivers in Jambi.

\section{CLOSING}

The findings of this studyare as follows the position of Jambi as one of the spice-producing centers as well as the open geographical conditions, allowing contact with foreign traders including Islamic traders from various regions, both from outside and from other parts of the archipelago. The emergence of Islamic kingdoms was one indication of the development of trade, as well as showing the influence of Islam that came from outside the Jambi Malay area.

The process of Islamization in Jambi is almost the same as in other areas in the archipelago. It begins with the arrival of a religious figure in an area and then spreads Islam. In the Jambi context, Islamization was preceded by the arrival of Ahmad Barus from Turkey, who is thought to have arrived in the 15 th century.

Islamization in Jambi has been successful, because the teachings of Islam still pay attention to the economic life of the community. In fact, economic activity becomes an opportunity for the convenience of preaching Islam to remote areas in the far upstream Jambi. Although no authentic source has been found, whether this preacher also participated in the trade when preaching Islam to the upstream area or was it just a ride on transportation. There is still a need for more in-depth research. However, what is clear is that the economic development from time to time has become an opportunity for

${ }^{64}$ Scholten, op cit, p. 42 
IJIERM: Vol. 2 No. 2 May - July 2020

the development of Islamic da'wah for the remoted community of rivers in Jambi. In other words, the trade route clearly had an influence on the Islamization process in Jambi, especially the remoted areas in the upstream Jambi Malay. 


\section{REFERENCES}

Ali Muzakkir, Islamic Thought in Jambi: Strengthening Islamic Studies through Local Manuscripts (Jambi: Sulthan Thaha Press, 2011)

Anthony Reid (ed.), Southeast Asia in the Early Modern Era: Trade, Power, and Beliefs (New York: Cornel University Press, 1993)

Bambang Budi Utomo and Nik Hasan Shuhaimi, Incription in ancient Malay in Southeast Asia (Bangi: Institute of Nature and Tamaddun Melayu (ATMA), 2009)

Bambang Budi Utomo, Classical Indonesian Culture in Batanghari (Jambi: Position of Culture and Tourism in Jambi Province, 2011)

Barbara Watson Andaya, 2016, Life for Brothers in Southeast Sumatra in the XVII and XVIII centuries. (Yogyakarta: Waves Publisher)

, To Live as Brothers: Southeast Sumatra in the Seventeenth and Eighteenth Centuries (Honolulu: University of Hawaii Press, 1993)

Berg, LWC van den. 2010. Arabs in the archipelago. Cet. 1. (Jakarta: Bamboo Community.)

Belwood, Peter, 2000. Prehistory of the Indo-Malaysian Archipelago. Revised Edition. (Jakarta: Gramedia Pustaka Utama)

Datuk Sangguno Dirajo, Mustika Adat Alam Minangkabau (Djakarta: Ministry of P \& K, 1955)

F. Hirth and WW Rokhill, Chau ju kua: His Work on the Chinese and Arab Trade in the Twelfth and Thirteenth Centuries (Saint Petersburg: Imperial Academy of Science, 1911)

Freek Colombijn, "Islamic Influences on Urban Form in Sumatra in Seventeenth to the Nineteenth century" Indonesia and the Malay World, 32 (2004)

Goerge Coedes, The Indianized States of Southeast Asia (Kuala Lumpur: Universiti Malaya Press, 1968)

Husin Thalib, Islam and Ethnicity in Malay Politics (Oxford: Oxford University Press, 1990)

Ibrahim Hadi, "The Influence of Islamic Education on the Jambi Chinatown Society", Thesis at IAIN Sunan Ampel, Surabaya, (1973) 
IJIERM: Vol. 2 No. 1 Januari - April 2020

Jan Vansina, Oral Tradition: A Study in Historical Methodology (Chicago: Aldine, 1965)

Junaidi T. Noor, Senjakala: threshing historical trinkets in Jambi (Jambi: Publisher Heritag, 2008)

JR Bowen, Sumatran Politics and Politics: Gayo History 1900-1989 (New Haven \& London: Yale University Press, 1991)

J. Takakusu, A Record of the Buddhist Religion as Practiced in India and the Malay Archipelago, 671-695 AD I-Tsing (Oxford: tp, 1896)

KA Nilakanta Sastri, History of Srivijaya (Madras: Madras University, 1949)

Lindayanti, et al, 2013, Jambi in History 1500-1942, (Jambi: Research Center for Historical and Cultural Development of Jambi)

Locher-Scholten, Elsbeth, 2008, the Sultanate of Sumatra and the Colonial State, Jambi-Batavia Relations (1830-1907) and the Rise of Dutch Imperialism. (Jakarta: Bamboo Community)

Martin van Bruinessen, "Muslim of the East Indies and Tea Chalipate Question" in Studia Islamika, 2, 3 (1995)

MB Hooker, Islam in South-East Asia (Leiden: E. J Brill, 1983) 